\title{
Validation of the names of some Cretan high mountain syntaxa, with considerations about Article 3i, ICPN
}

\author{
Erwin Bergmeier ${ }^{1}$, Jean-Paul Theurillat ${ }^{2,3}$ \\ 1 Department Vegetation Analysis \& Plant Diversity, University of Göttingen, Göttingen, Germany \\ 2 Fondation J.-M.Aubert, Champex-Lac, Switzerland \\ 3 Département de Botanique et Biologie végétale, Section de Biologie, Université de Genève, Chambésy, Switzerland \\ Corresponding author: Erwin Bergmeier (erwin.bergmeier@bio.uni-goettingen.de)
}

Academic editor: Wolfgang Willner • Received 11 January 2021 • Accepted 24 February 2021 Published 15 March 2021

\begin{abstract}
To comply with the International Code of Phytosociological Nomenclature (ICPN), we validate the names Saturejo spinosae-Scutellarietalia hirtae, Arenarion creticae, Verbascion spinosi and Lomelosio sphacioticae-Centranthetum sieberi. Two divergent interpretations of Article $3 \mathrm{i}$ about the point at issue in the validation of the first three names are discussed.
\end{abstract}

Syntaxonomic reference: Bergmeier (2002), unless indicated otherwise in the text.

\section{Keywords}

Crete, high mountains, phytosociology, syntaxon, validation

\section{Introduction}

In a monographic paper on the vegetation of the high mountains of Crete, Bergmeier (2002) described as new the associations Arenario fragillimae-Silenetum antri-jovis, Berberido creticae-Astragaletum cretici, Cicero incisi-Silenetum variegatae, Fumano paphlagonicae-Helianthemetum hymettii, Gypsophilo nanae-Arenarietum creticae, Hyperico kelleri-Anchusetum cespitosae, Paronychio macrosepalae-Juniperetum oxycedri and Sideritido syriacae-Verbascetum spinosi, as well as the alliances Alysso sphaciotici-Valantion apricae, Astragalion cretici and Colchico cretensis-Cirsion morinifolii.

While the names of these syntaxa had been validly published, the author further intended to validate the names of four other syntaxa, namely the alliance Arenarion creticae and the order Saturejo-Scutellarietalia, both invalidly (ICPN Art. 5) proposed "ad interim" by Dimopoulos et al. (1997: 334), as well as the Verbascion spinosi in Zaffran (1990: 470) and the Lomelosio sphacioticae-Centranthetum sieberi in Zaffran (1990: 529). As argued below, one can consider that the attempt to validate the first three names failed because the provisions of Article $3 \mathrm{i}$ of ICPN (Theurillat et al. 2021) were not fulfilled.

With this nomenclatural note we validate these names in following the syntaxonomic concept of Bergmeier (2002) that is also adopted in the EuroVegChecklist (Mucina et al. 2016). At the same time, having been made aware during the revision process that the underlying nomenclatural question is disputable, we discuss the critical point at issue.

\section{Interpretation of Article 3i with regard to the validation of syntaxon names}

Among the reasons causing the invalidity of a syntaxon name, Art. 3i states: "When it has been published on or after 1 January 2002 without being indicated explicitly as

Copyright Erwin Bergmeier, Jean-Paul Theurillat. This is an open access article distributed under the terms of the Creative Commons Attribution License (CC-BY 4.0), which permits unrestricted use, distribution, and reproduction in any medium, provided the original author and source are credited. 
new". Despite the term 'explicit' appears to be clear, interpretations are nonetheless possible. Thus, it might be disputed whether the present validation of three of the names addressed (Saturejo spinosae-Scutellarietalia hirtae, Verbascion spinosi and Arenarion creticae) is necessary, arguing that the wording 'valid. hoc loco' used by Bergmeier (2002: 242-244) in his attempt to validate the names is to be regarded as an 'explicit indication as new' in the sense of Art. 3i.

By stating valid. hoc loco (as against merely valid., which might indeed refer to someone and somewhere else's validation) Bergmeier (2002) intended to designate, by validation, unambiguously referenced, the hitherto invalid names as new. In his attempt, Bergmeier (2002) did not want to claim the authorship of the syntaxa but to perform merely the formal act of validation, while appreciating the fact that the novel syntaxa were described, though invalidly, by the original authors. Although it is evident that the names of the syntaxa that Bergmeier (2002) attempted to validate were not accompanied by the literal expression of 'new', the aim of the author was nevertheless made clear in the abstract in specifying the "... nomenclaturally relevant new or validated names", and in using for each of the allegedly validated names the indication valid. hoc loco (Bergmeier 2002: 240-243). The question is whether the implicitly clear approach is sufficiently explicit regarding Art. 3i.

The indication valid. hoc loco used by Bergmeier (2002) may well imply that this expression is sufficiently unambiguous (arguably even less ambiguous, or more explicit, than some expressions used in vernacular languages accepted by Art. 3i until 31 December 2020). The then authoritative third edition of the ICPN (Weber et al. 2000), Art. 6, stated that "... a provisional name is validated only when the validation is indicated expressis verbis, and all other conditions are fulfilled (see Art. 3i)", which suggested that a particular expressis verbis indication was needed when validating, and that the expression valid. hoc loco (in full: validatio hoc loco) would be adequate in this respect. However, Art. 3i of the same edition established that names are invalid when published on or after 1 January 2002 "without being indicated expressis verbis as new (e.g. 'ass. nov.,' 'all nov.,' 'comb. nov., 'stat. nov.,' 'nom. nov., etc.); this applies also to the validation of invalidly published names".

The expression expressis verbis (literally in express terms') used in the third edition of the ICPN means 'explicitly' (which is the term used in the $4^{\text {th }}$ edition of the ICPN), that is directly, unambiguously stated, not left to implication. In writing valid. hoc loco, Bergmeier (2002) did not comply with an explicit indication. Since an explicit indication of 'new' was requested in 2002 (Art. 3i), this provision should have been effectively published as part of the publication of the missing provisions according to Art. 6 in order to validate the names Saturejo spinosae-Scutellarietalia hirtae, Verbascion spinosi and Arenarion creticae. Therefore, when Bergmeier (2002) wrote in the abstract: "A hierarchical conspectus of the syntaxa is provided which includes the following nomenclaturally relevant new or validated names of various ranks ..., he made a distinction between the names he described as new and those he attempted to validate, without explicitly indicating the validated names as new.

Since it is desirable for the sake of stability to keep the names in question in their syntaxonomic circumscription as provided by Bergmeier (2002) and as they are retained by Mucina et al. (2016), we provide below their formal validation in accordance with a strict, formal interpretation of Art. 3i. At the same time, we acknowledge that a more precise wording of Art. $3 i$ or a binding decision by the Committee of Change and Conservation of Names $(\mathrm{CCCN})$ on this case might be desirable.

\section{Validations}

(1) Saturejo spinosae-Scutellarietalia hirtae Dimopoulos et al. ex Bergmeier ord. nov. - Typus: Verbascion spinosi Zaffran ex Bergmeier hoc loco (see below). Diagnostic species: table 9 in Bergmeier (2002).

The Saturejo spinosae-Scutellarietalia hirtae was to be validated by selecting the alliance Verbascion spinosi published in Zaffran (1990: 470) as the nomenclatural type (Bergmeier 2002: 241). However, the attempt to validate the Verbascion spinosi chosen as the type failed (see below) and, consequently, that of the order's name (Art. 3o).

(2) Verbascion spinosi Zaffran ex Bergmeier all. nov. Typus: Sideritido syriacae-Verbascetum spinosi Bergmeier 2002 (Bergmeier 2002: 242). Diagnostic species: table 9 in Bergmeier (2002: 241).

The name Verbascion spinosi was invalidly published in Zaffran (1990: 470) because of a missing type (Arts. 3o and $5)$. In his attempt to validate the name, Bergmeier (2002: $239,242)$ designated a type. However, the name was not explicitly indicated as new. Consequently, the attempt to validate failed since on or after 1 January 2002 the 'explicit indication as new' is requested for the valid publication of a name (Arts. 3i and 6).

(3) Arenarion creticae Dimopoulos et al. ex Bergmeier all. nov. - Typus: Gypsophilo nanae-Arenarietum creticae Bergmeier 2002 (Bergmeier 2002: 240). Diagnostic species: table 10 in Bergmeier (2002: 243).

The Arenarion creticae was invalidly (Art. 5) published “ad interim" by Dimopoulos et al. (1997: 334). In his attempt to validate the name, Bergmeier (2002: 240) designated a type but did not explicitly indicate the name as new. Consequently, the attempt to validate failed since on or after 1 January 2002 the 'explicit indication as new' is requested for the valid publication of a name (Arts. 3i and 6).

(4) Lomelosio sphacioticae-Centranthetum sieberi Zaffran ex Bergmeier ass. nov. - Typus: relevé 48, separate table 29 in Zaffran (1990).

The name 'Lomelosio-Kentranthetum sieberi' was not validly published in Zaffran (1990: 529) because 
no type was given for this new association (Art. 5). In his attempt to validate the name, Bergmeier (2002: 243) selected the relevé 35 of the separate table 29 in Zaffran (1990) as typus. However, one of the name-giving taxa, Centranthus sieberi Heldr., is missing in that relevé. Consequently, the attempt to validate failed (Arts. 3o, 5 and 16). The relevé 48 selected here is the only relevé in Zaffran (1990, table 29) that contains both namegiving species, and hence the only element suitable as the type relevé.

\section{References}

Bergmeier E (2002) The vegetation of the high mountains of Crete - a revision and multivariate analysis. Phytocoenologia 32: 205-249. https://doi.org/10.1127/0340-269X/2002/0032-0205

Dimopoulos P, Sýkora KV, Mucina L, Georgiadis T (1997) The high-rank syntaxa of the rock-cliff and scree vegetation of the mainland Greece and Crete. Folia Geobotanica et Phytotaxonomica 32: 313-334. https://doi.org/10.1007/BF02804010

Mucina L, Bültmann H, Dierßen K, Theurillat J-P, Raus T, Čarni A, Šumberová K, Willner W, Dengler J, ..., Tichý L (2016) Vegetation of Europe: Hierarchical floristic classification system of vascular plant, bryophyte, lichen, and algal communities. Applied Vegetation Science 19 (Suppl. 1): 3-264. https://doi.org/10.1111/avsc.12257

\section{Author contributions}

Both authors contributed in equal parts.

\section{Acknowledgements}

We appreciate the valuable advice provided by two reviewers and the editor Wolfgang Willner as well as his editorial work.

Theurillat J-P, Willner W, Fernández-González F, Bültmann H, Čarni A Gigante D, Mucina L, Weber H (2021) International Code of Phytosociological Nomenclature. $4^{\text {th }}$ edition. Applied Vegetation Science 24: e12491. https://doi.org/10.1111/avsc.12491

Weber HE, Moravec J, Theurillat J-P (2000) International Code of Phytosociological Nomenclature. $3^{\text {rd }}$ edition. Journal of Vegetation Science 11: 739-768. https://doi.org/10.2307/3236580

Zaffran J (1990) Contributions à la flore et à la végétation de la Crète. Publications de l'Université de Provence, Aix en Provence, FR, 615 pp. [+ 30 separate tables in envelope]

\section{E-mail and ORCID}

Erwin Bergmeier (Corresponding author, erwin.bergmeier@bio.uni-goettingen.de), ORCID: https://orcid.org/00000002-6118-4611

Jean-Paul Theurillat (jean-paul.theurillat@unige.ch), ORCID: https://orcid.org/0000-0002-1843-5809 